\title{
Redesain Terminal Seruni Dengan Penekanan Sistem WAyfinding Di Cilegon, BANTEN
}

\author{
Yudistira Miranti Lestari, Tri Joko Daryanto, Maya Andria Nirawati \\ Program Studi Arsitektur \\ Fakultas Teknik \\ Universitas Sebelas Maret Surakarta \\ Email : yudistiramiranti@gmail.com
}

\begin{abstract}
Bus terminal in its role to help facilitating transportation activities especially in the distribution process of passengers in a city currently is not functioning optimally, as happened in Terminal Seruni Cilegon, Banten. Terminal which has supported regional scale transportation services (categorized as B type) with additional operating for AKAP, it's still categorized as $C$-type terminal with an area of \pm 2 hectares, so that, both of main and supporting facilities have not been able to accommodate the functions of the current terminal activities. The function of this terminal which is still lacking, stimulate a behavior of public transportation, buses and passengers were reluctant to enter the terminal, instead they are moving to an area outside the Terminal, especially at area of Cilegon highway, which cause traffic jams in the area. The design issue is how to make a redesign concept of Terminal Seruni in Cilegon, Banten with the emphasis of wayfinding systems in facilitating user's mobility to provide efficient orientation. The objective is to improve the quality of the buildings and restore the function and activity of area of East Cilegon highway into the area of Terminal Seruni. The method used is a method of designing architecture with the emphasis of wayfinding system. The results obtained are re-design with the emphasis of wayfinding system in Terminal Seruni which is applied in the space program based on zoning and spatial layout to determine the user's movement; lane separation for pedestrians and vehicles which can be supported with tools to help the orientation; circulation that provides comfort and ease of movement for the user, both circulation of vehicles and humans so that it will increase the efficiency of circulation in Terminal Seruni; as well as the design of the building that representative through the presence of a landmark combined with a sign or other additional sensors to strengthen the identity of Terminal Seruni.
\end{abstract}

Keywords: Re-design, Bus Terminal, Wayfinding Systems, Efficiency Of Circulation

\section{PENDAHULUAN.}

Terminal merupakan salah satu unsur tata ruang yang mempunyai peranan penting bagi efisiensi kehidupan kota (Petunjuk Teknis LLAJ Tahun 1995). Terminal menjadi sangat penting karena fungsinya sebagai tempat perpindahan penumpang antar moda, tempat naik atau turunnya penumpang, tempat pendataan angkutan umum serta sebagai tempat melakukan pemeriksaan terhadap kelaikan kendaraan umum, sebagaimana diamanatkan dalam Undang-Undang Nomor 22 tahun 2009 tentang Lalu Lintas dan Angkutan Jalan. Menurut data Badan Pusat Statistik Tahun 2010-2014 jumlah kendaraan bermotor khususnya bus berturut-turut mengalami peningkatan yaitu 2.250.109 kendaraan, 2.254.406 kendaraan, 2.273.821 kendaraan, 2.286.309 kendaraan, 2.398.846 kendaraan. Berdasarkan data tersebut, dibutuhkan simpul transportasi antar moda transportasi umum atau angkutan jalan yang tertata dalam satu tempat yang terpadu yakni terminal bus. Namun, saat ini terminal bus dalam perannya membantu memperlancar kegiatan transportasi terutama dalam proses pendistribusian penumpang suatu kota belum berfungsi secara optimal memenuhi kebutuhan masyarakat.

Kondisi inilah yang terjadi di Terminal Seruni. Terminal yang berlokasi di kawasan dekat Tol Cilegon Timur wilayah Kecamatan Cibeber ini, merupakan terminal satu- satunya bertipe B (berdasarkan Rencana Tata Ruang Wilayah Provinsi Banten Tahun 2010- 2030). Terminal Seruni yang kehadirannya 
diharapkan dapat memenuhi besarnya tuntutan kebutuhan sarana dan prasarana transportasi yang menggunakan jasa terminal angkutan umum, ternyata memiliki banyak permasalahan dalam perannya mewadahi kegiatan mobilitas masyarakat Kota Cilegon.

Beberapa temuan permasalahan pada Terminal Seruni, berdasarkan evaluasi purna huni (EPH) terhadap aspek teknis, fungsi, serta perilaku, antara lain: Terminal Seruni yang telah mendukung pelayanan transportasi skala regional (termasuk kategori tipe B) dengan operasional tambahan untuk AKAP, saat ini masih termasuk kategori terminal tipe $\mathrm{C}$ dengan luas area \pm 2 hektar . Hal ini tidak sesuai dengan RTRW (Rencana Tata Ruang dan Wilayah) Kota Cilegon tahun 2010- 2030 yaitu Terminal Seruni merupakan terminal dengan tipe $B$, sehingga baik fasilitas utama maupun penunjangnya belum mampu mewadahi fungsi kegiatan terminal saat ini; ruang pada bangunan utama terminal kurang memenuhi tata letak pola hubungan ruang dan mengalami disfungsi; tidak adanya pemisahan area sirkulasi antara kendaraan pengunjung dengan bus. Kurang optimalnya fungsi terminal ini mendukung timbulnya perilaku baik bus, angkutan serta penumpang yang enggan naik, turun serta perpindahan moda di dalam Terminal Seruni dan beralih menggunakan area luar Terminal Seruni terutama pada area pertigaan Tol Cilegon sehingga menyebabkan kemacetan lalu lintas pada area tersebut.

Kondisi ini cukup disayangkan mengingat Terminal Seruni memiliki peranan penting untuk Kota Cilegon dalam rangka untuk menunjang arus pergerakan regional di provinsi Banten, khususnya lingkungan Kecamatan Cibeber, Kota Cilegon. Didukung letak Kota Cilegon yang strategis yaitu berhubungan langsung dengan selat sunda, jalan Tol Jakarta - Merak, dan merupakan pintu gerbang lintasan pergerakan lalu lintas Jawa-Sumatera. Hal tersebut memberi keuntungan untuk Kota Cilegon sebagai kota penyangga Ibukota provinsi Banten yaitu menjadi simpul jasa dan distribusi yang akan terus berkembang. Oleh karena itu, diperlukan langkah redesain pada Terminal Seruni untuk meningkatkan kualitas bangunan dan mengembalikan fungsi peranan serta kegiatan pengguna dari area pertigaan Tol Cilegon
Timur ke dalam kawasan Terminal Seruni. Redesain Terminal Seruni ini direncanakan menerapkan sistem wayfinding. Wayfinding sendiri dapat didefinisikan sebagai kemampuan untuk menemukan jalan menuju suatu lokasi (Passini, R. 1984).

Penerapan sistem wayfinding, sebagai solusi permasalahan dalam memenuhi kebutuhan pengguna akan efisiensi dalam mobilitas. Sistem perpindahan yang jelas dan cepat akan menghindarkan dari kerugian biaya, waktu, dan kebingungan pengguna yang berdampak pada fisik dan mental pengguna, sehingga diperlukan penataan ruang dan sirkulasi yang tidak memicu kebingungan pengguna. Sistem wayfinding akan mengarahkan kegiatan pengguna terminal agar tidak kembali menggunakan lokasi yang berada di area pertigaan Tol Cilegon Timur, untuk mengoptimalkan kegiatan maupun fungsi pada Terminal Seruni.

\section{METODE}

Berdasarkan konsep perencanaan dan perancangan, redesain Terminal Seruni yang direncanakan menerapkan sistem wayfinding, yaitu pada aspek peruangan dan tata massa, pencapaian, sirkulasi, dan tampilan bangunan.

Aspek peruangan dan tata massa yaitu melalui program ruang yang disesuaikan dengan kegiatan pengguna Terminal Seruni. Pada aspek pencapaian tapak sistem wayfinding dengan tuntutan gerak efisien dalam mengakomodasi pengguna Terminal Seruni diaplikasikan berupa pemisahan jalur bagi pejalan kaki dengan jalur kendaraan dan didukung dengan alat pembantu orientasi. Aspek sirkulasi diaplikasikan melalui perbedaan tekstur dan warna pada nodes, path baik di luar maupun di dalam bangunan untuk memberikan kenyamanan dan kemudahan pergerakan pengguna. Selain itu, aspek tampilan bangunan melalui landmark yang dipadukan dengan penanda atau sensor tambahan untuk menguatkan identitas Terminal Seruni sebagai terminal bus.

\section{ANALISIS}

\subsection{Analisis Peruangan}

1. Tujuan: Ruang-ruang yang dibutuhkan berdasarkan jenis kegiatan yang dilakukan oleh pengguna 
2. Dasar Pertimbangan: Berdasarkan analisis pelaku dan jenis kegiatan, kelompok kegiatan dan pola kegiatan pelaku.

3. Proses Analisis: Kebutuhan ruang di Terminal Seruni dibedakan menjadi ruang dalam dan luar.

Tabel 1. Kebutuhan Ruang

\begin{tabular}{|c|c|c|}
\hline $\begin{array}{c}\text { Pelaku } \\
\text { Kegiatan }\end{array}$ & $\begin{array}{c}\text { Jenis } \\
\text { Kegiatan } \\
\end{array}$ & $\begin{array}{c}\text { Kebutuhan } \\
\text { Ruang }\end{array}$ \\
\hline \multirow{7}{*}{ Pengelola } & Datang-Pergi & $\begin{array}{l}\text { Main Entrance } \\
\text { - Side Entrance } \\
\text { exit I }\end{array}$ \\
\hline & Parkir & $\begin{array}{l}\text { Tempat Parkir } \\
\text { Pengelola }\end{array}$ \\
\hline & Bekerja & $\begin{array}{l}\text { R. Pengelola, } \\
\text { R. Staff. }\end{array}$ \\
\hline & $\begin{array}{l}\text { Menerima } \\
\text { Tamu }\end{array}$ & R. Tamu \\
\hline & Beristirahat & Musholla \\
\hline & $\begin{array}{l}\text { Memanfaat- } \\
\text { kan Fasilitas }\end{array}$ & $\begin{array}{l}\text { Pantry, Ruang } \\
\text { Merokok. }\end{array}$ \\
\hline & Metabolisme & Toilet \\
\hline \multirow{7}{*}{ Pengunjung } & Datang-Pergi & $\begin{array}{l}\text { Main Entrance } \\
\text { - Side Entrance } \\
\text { exit I }\end{array}$ \\
\hline & Parkir & $\begin{array}{l}\text { Tempat Parkir } \\
\text { Pengunjung }\end{array}$ \\
\hline & $\begin{array}{l}\text { Mencari } \\
\text { Informasi }\end{array}$ & $\begin{array}{l}\text { Ruang } \\
\text { Informasi }\end{array}$ \\
\hline & $\begin{array}{l}\text { Mengantar } \\
\text { atau } \\
\text { Menunggu } \\
\text { Penumpang }\end{array}$ & $\begin{array}{l}\text { Ruang Tunggu } \\
\text { Kedatangan } \\
\text { Keberangkatan } \\
\text { Bus } \\
\end{array}$ \\
\hline & $\begin{array}{l}\text { Membeli } \\
\text { Tiket }\end{array}$ & $\begin{array}{l}\text { Ruang Loket } \\
\text { Tiket }\end{array}$ \\
\hline & $\begin{array}{l}\text { Memanfaat- } \\
\text { kan Fasilitas }\end{array}$ & $\begin{array}{l}\text { Foodcourt, } \\
\text { Retail, Ruang } \\
\text { Ibu dan Anak, } \\
\text { Ruang } \\
\text { Merokok, } \\
\text { Ruang } \\
\text { Kesehatan, } \\
\text { Musholla } \\
\end{array}$ \\
\hline & Metabolisme & Toilet \\
\hline
\end{tabular}

Pada Tabel 1 dapat diketahui ruang-ruang yang dibutuhkan dalam pemenuhan wadah Terminal Seruni.

\subsection{Analisis Lokasi}

Tapak Terminal Seruni saat ini, berada di wilayah Kecamatan Cibeber dengan luas \pm 2 hektar, kurang memenuhi persyaratan kebutuhan luasan untuk terminal tipe $b$ dengan operasional tambahan AKAP.

1. Tujuan: Lokasi perluasan yang sesuai kebutuhan untuk redesain terminal bus pada Terminal Seruni di Kota Cilegon, Banten.

2. Dasar Pertimbangan: Luas lahan mencukupi kebutuhan; sebagian tapak merupakan area lahan saat ini, sehingga mengurangi adanya bukaan lahan baru; sesuai dengan RTRW (Rencana Tata Ruang Wilayah) Kota Cilegon, Banten.

3. Proses Analisis: Berdasarkan batas- batas tapak diperoleh potensi perluasan tapak berada pada sisi barat tapak yang merupakan area lahan kosong, sehingga luas tapak keseluruhan $\pm 45.000 \mathrm{~m}^{2}$.

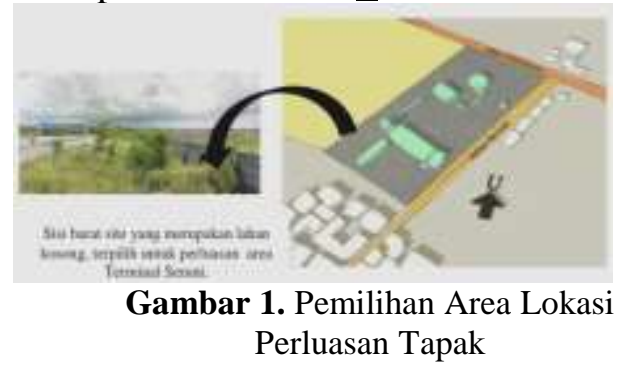

Pada Gambar 1 terlihat area berwarna kuning yang merupakan area perluasan tapak .

\subsection{Analisis Pencapaian}

Pencapaian ke dalam bangunan harus mudah dilihat dan diakses, serta adanya pemisahan akses keluar-masuk antar pengguna agar tidak terjadi crossing.

1. Tujuan: Aplikasi elemen wayfinding berupa path, sign, dan jalur pejalan kaki yang dibedakan dengan jalur kendaran dalam mengakomodasi pergerakan pengguma mendukung letak main entrance (ME), side entrance (SE) dan pintu keluar.

2. Dasar Pertimbangan: Nilai aksesibilitas dan keamanan pencapaian ke dalam maupun keluar site dan tidak mengganggu arus lalu lintas umum. Penerapan elemen wayfinding berupa path serta jalur pejalan kaki yang dibedakan dengan jalur kendaraan yang strategis serta aplikasi 
sign, dapat mudah dibaca dan ditangkap oleh mata pengguna terminal, sehingga menghindari disorientasi arah.

3. Proses Analisis

Main Entrance (ME)

Mudah dijangkau dan terlihat dengan jelas. Main Entrance (ME) pada tapak diletakkan di sisi jalan Kesultanan tepatnya di bagian utara tapak. Diperuntukkan bagi pengguna moda bus, mobil, motor, dan pejalan kaki.

Side Entrance (SE)

Tidak mengganggu keberadaan ME. Diperuntukkan sebagai sirkulasi angkutan umum, taksi, ojek dan akses loading dock.

Main Entrance Exit

Berada di sisi jalan Kesultanan merupakan akses keluar untuk bus

Side Entrance Exit I

Berada di sisi jalan Seruni merupakan akses untuk mobil dan motor

Side Entrance Exit II

Diperuntukkan jalur keluar angkutan umum, taksi, ojek dan loading dock.

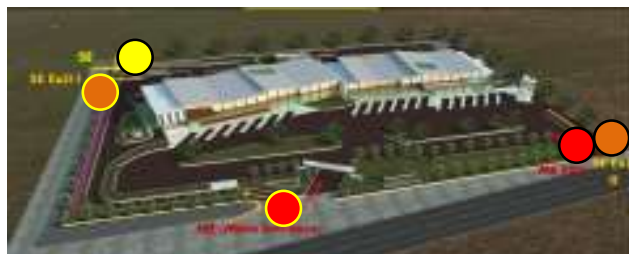

Gambar 2. Letak Akses Masuk dan Keluar pada Tapak.

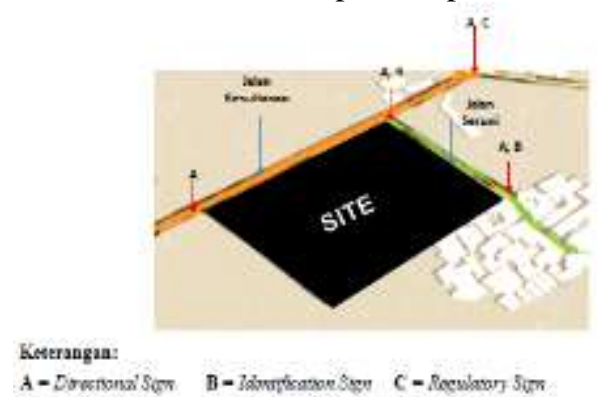

Gambar 3. Aplikasi Peletakkan Sign pada Tapak

Pada Gambar 4 aplikasi sign diletakkan pada titik area yang memungkinkan terjadinya disorientasi, sehingga adanya sign ini membantu pengguna berorientasi lebih efisien.

\subsection{Analisis Pemintakatan (Penzoningan)}

1.Tujuan: Pemintakatan yang tepat sesuai kondisi tapak
2. Dasar Pertimbangan: Memiliki kesamaan karakteristik atau peta kognisi pengguna diperoleh dari pengelompokkan ruang kegiatan yang telah ditentukan sebelumnya, dan kemudahan akses antar mintakat (zoning).

3. Proses Analisis: Persyaratan ruang, berdasarkan kelompok kegiatan dan analisis pengolahan tapak.

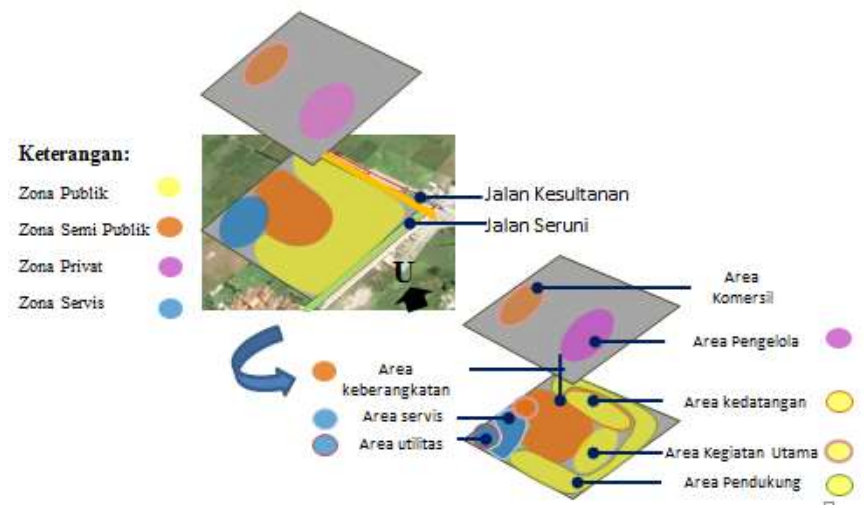

Gambar 4. Pemintakatan pada Massa Bangunan

Pada Gambar 4 pemintakatan dibedakan menjadi empat bagian, yaitu area publik, semi publik, privat, dan servis.

\subsection{Analisis Bentuk dan Tata Massa}

Bentuk dan tampilan dasar massa bangunan dipertimbangkan dari pengolahan bangun dasar. Bentuk segiempat ditata dengan menggunakan pola penataan massa tunggal.

1. Tujuan: Aplikasi elemen wayfinding berupa bentuk, ukuran tekstur dan material, serta warna. Aplikasi elemen ini sebagai upaya untuk memberikan persepsi ruang bagi pengguna, sehingga pengguna dapat mengidentifikasi ruangruang dan berorientasi secara mandiri.

2. Dasar Pertimbangan: Efisiensi dan fleksibilitas; penataan massa dari ruangruang didalamnya dilakukan secara berurutan sesuai fungsi ruang pencapaiannya, namun dapat dibedakan antara ruang satu dengan yang lain, bersifat imageability dan legibility, penataan mudah terlihat dan tidak menghalangi sirkulasi, memaksimalkan pencahayaan dan penghawaan alami.

3. Proses Analisis: Bentuk dasar persegi panjang ditransformasikan menjadi 
bentuk massa bangunan yang menyesuaikan dengan fungsi dan kebutuhan ruang yang ada di dalamnya, serta perletakkan massa pada tapak disesuaikan dengan mintakat (zoning) yang sebelumnya telah dianalisis.

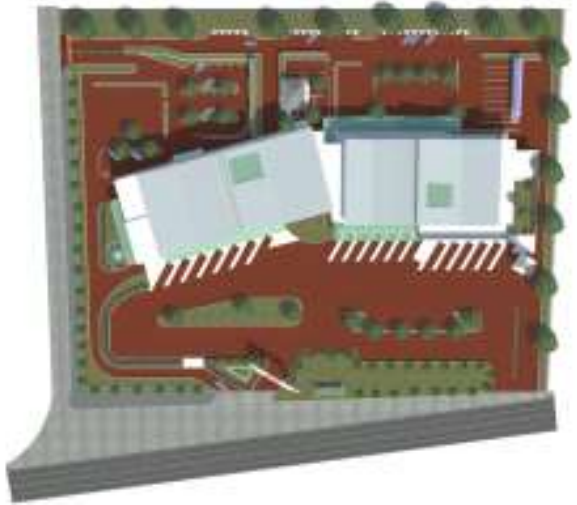

Gambar 5. Situasi Tapak

Pada Gambar 5 terlihat bentuk bangunan pada tapak dengan bentuk persegi panjang dengan pola penataan massa tunggal.

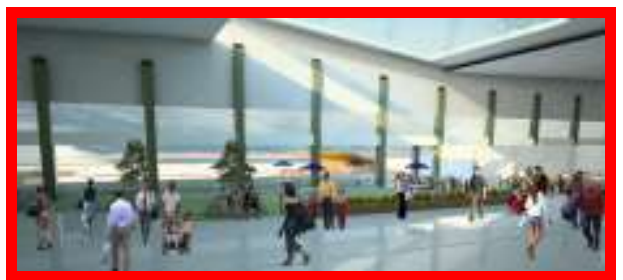

Gambar 6. Interior Foodcourt

Pada Gambar 6 terlihat bentuk ruang foodcourt yang menerapkan skylight, sebagai pembeda dengan ruang lain sehingga bersifat imageability dan legibility .

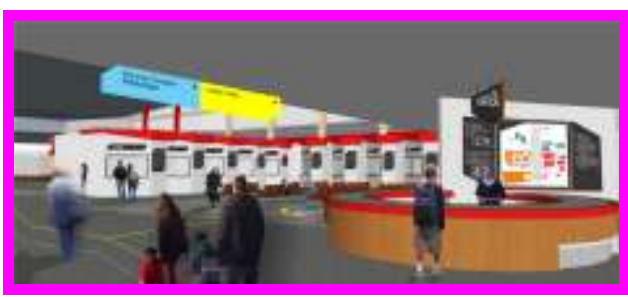

Gambar 7. Interior Ruang Informasi dan Loket Tiket

Pada Gambar 7 terlihat aplikasi warna dominan pada area ruang informasi dan loket tiket memberikan kesan imageability dan legibility bagi pengguna ruang.

\subsection{Analisis Sirkulasi}

1. Tujuan: Aplikasi sistem wayfinding pada sirkulasi, yaitu berupa nodes, path, dan penggunaan tekstur, material serta warna untuk penerapannya pada sirkulasi bangunan Terminal Seruni.

2. Dasar pertimbangan: Jalan masuk dan keluar kendaraan lancar dan dapat bergerak dengan mudah serta memberikan kenyamanan dan kemanan bagi seluruh pengguna, meminimalkan terjadinya cross melalui pemisahan jalan masuk dan keluar, mudah dimengerti dan mengarahkan pengguna melakukan keputusan dengan baik untuk mencapai tujuan.

3. Proses Analisis: sirkulasi terbagi atas sirkulasi horisontal dan vertikal.

4.
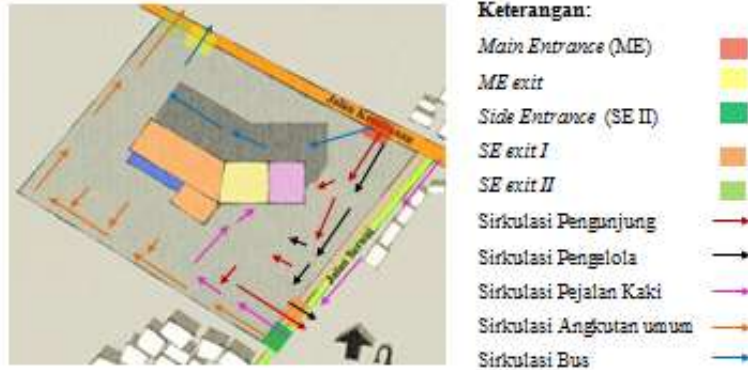

Gambar 8. Sirkulasi Horisontal
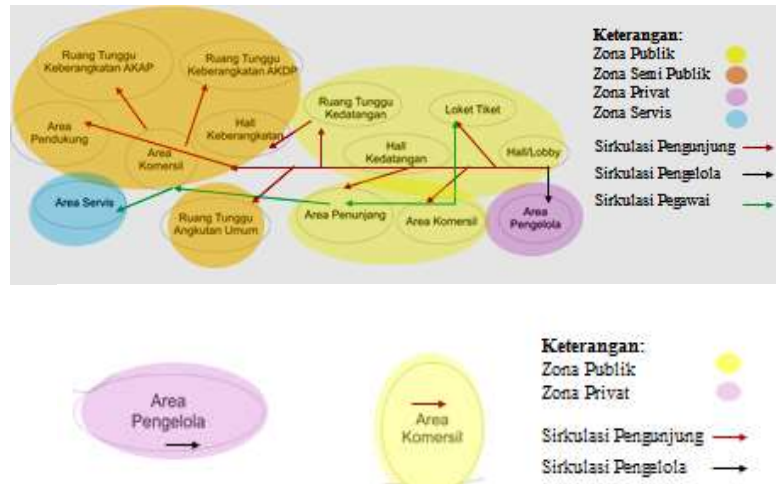

Gambar 9. Sirkulasi Horisontal

Pada Gambar 9 area dalam bangunan Terminal Seruni terbagi atas lantai dasarlantai I (atas- bawah) 


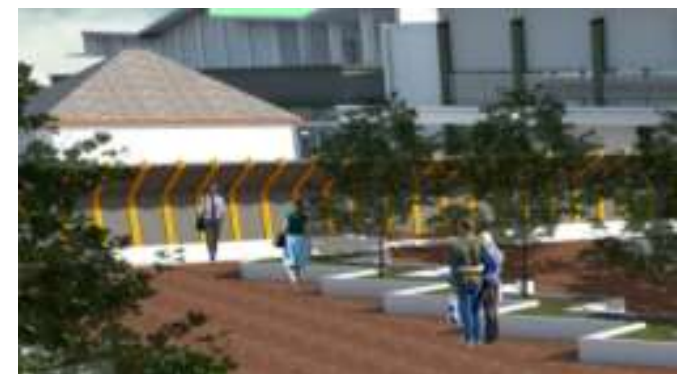

Gambar 10. Area Pedestrian

Pada Gambar 9 Penggunaan warna dominan pada fasilitas pedestrian, sebagai imageability dan legibility untuk mengarahkan pengguna ke pintu masuk bangunan.

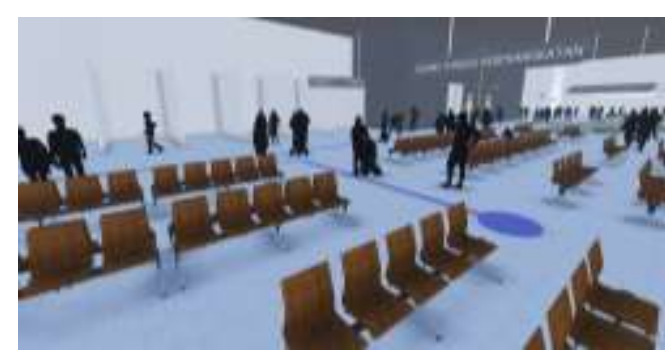

Gambar 11. Interior Ruang Tunggu

Pada Gambar 11 material yang dipadukan dengan warna pada area path, nodes untuk mendukung sirkulasi pengguna di dalam bangunan.

Sirkulasi vertikal pada Terminal Seruni diterapkan penggunaan ramp dan tangga. Aplikasi ramp akan diterapkan pada kanopi yaitu akses menuju dan keluar bangunan, sedangkan tangga akan diterapkan untuk sirkulasi pengelola menuju kantor pengelola yang berada di lantai satu, menara pengawas, dan bagi pengunjung yang akan ke area komersil yang berada di lantai satu.

\subsection{Analisis Tampilan Bangunan}

1. Tujuan: Aplikasi sistem wayfinding pada tampilan bangunan, yaitu berupa landmark, yang dipadukan dengan penanda atau sensor tambahan untuk menguatkan identitas Terminal Seruni.

2. Dasar pertimbangan: Bersifat mudah dikenali sebagai terminal bus, mudah dilihat dan diingat.

3. Proses analisis: Landmark sebagai elemen wayfinding memiliki peran membantu pengguna dalam mengingat dan mengorientasikan pada suatu lingkungan. Adapun untuk menghadirkan elemen landmark yang potensial, didukung dengan elemen lainnya seperti warna dan dekorasi serta ornamentasi, sehingga akan menghasilkan landmark yang mudah diingat, menginformasikan serta mengorientasikan pengguna nantinya.

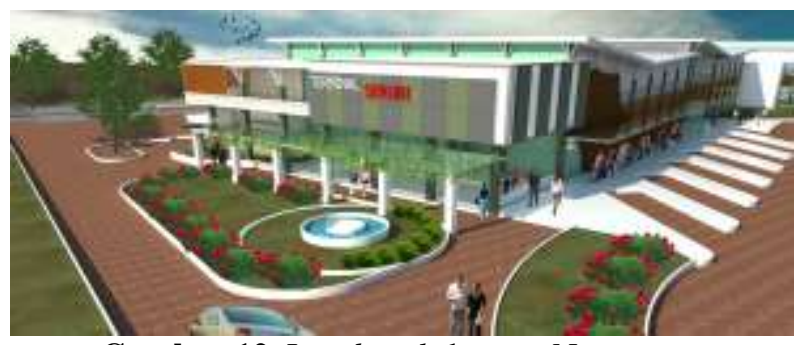

Gambar 12. Landmark. berupa Nama Terminal Seruni,

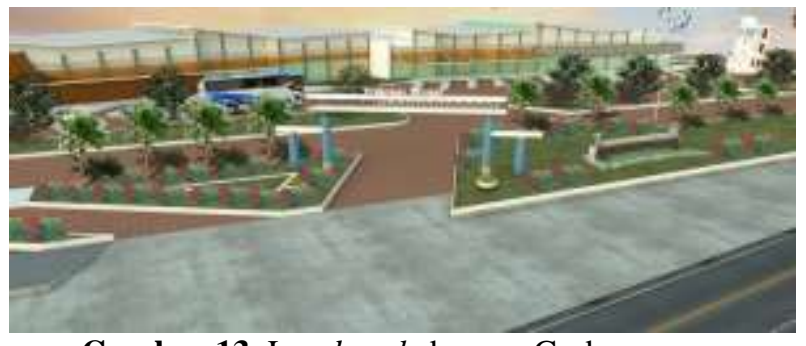

Gambar 13. Landmark. berupa Gerbang Masuk

Pada Gambar 12 dan 13 landmark, diletakkan menghadap ke arah jalan yaitu Jalan Seruni dan Jalan Kadipaten yang berpotensi sebagai view to site.

\section{KESIMPULAN (KONSEP DESAIN)}

Konsep rancangan Redesain Terminal Seruni mengacu pada penekanan Sistem Wayfinding yang berfokus pada kebutuhan pengguna akan efisiensi dalam mobilitasnya yang diakukan dengan mempertimbangkan aspek peruangan dan tata massa, pencapaian, sirkulasi dan tampilan bangunan.

Berdasarkan hasil analisis serta korelasi dari beberapa data di atas, maka diperoleh hasil berupa rancangan Redesain Terminal Seruni di Kota Cilegon, Banten sebagai berikut:

Nama Bangunan : Terminal Seruni

Lokasi : Kecamatan Cibeber, Kota

$\quad: \pm 45.000 \mathrm{~m}^{2}$

Luas Bangunan : $\pm 21.204,26 \mathrm{~m}^{2}$ 
Kegiatan

$$
\begin{aligned}
& \text { : Fasilitas naik dan turun } \\
& \text { penumpang dalam provinsi } \\
& \text { dan antar provinsi. }
\end{aligned}
$$

Pengolahan dan penataan massa peruangan di dalam rencana tapak dan denah lantai dasar dapat dilihat pada Lampiran 1 dan denah lantai pada Lampiran 2.

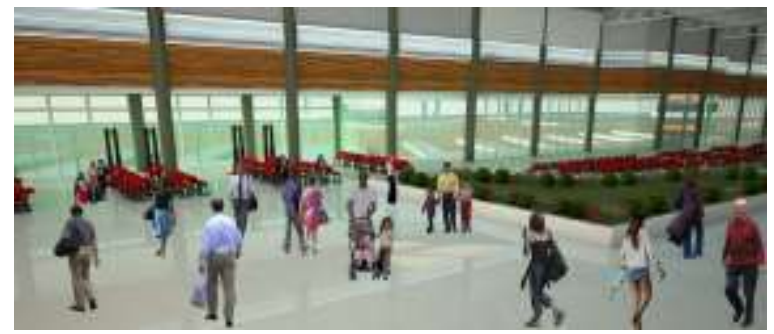

Gambar 14. Interior Ruang Tunggu Keberangkatan AKAP

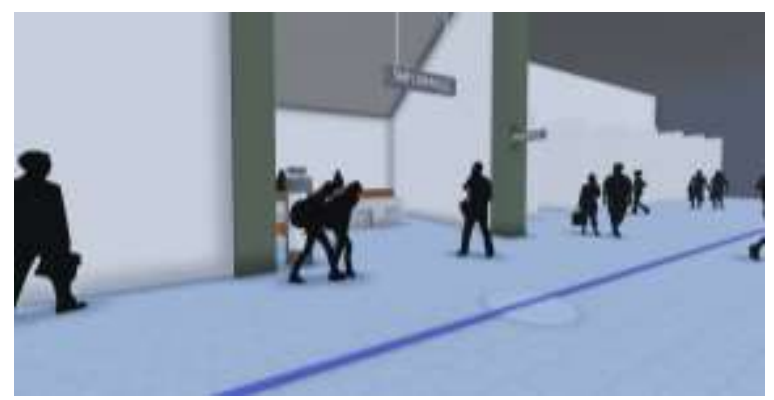

Gambar 15. Ruang Informasi Keberangkatan

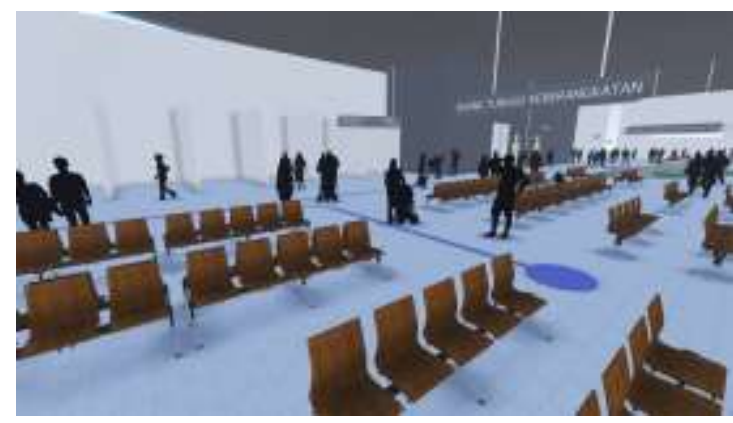

Gambar 16. Interior Ruang Tunggu Keberangkatan AKDP

Pada Gambar 14, 15 dan 16 terlihat aplikasi elemen warna, sign, dan material dalam mendukung orientasi pengguna di dalam bangunan Terminal Seruni.

\section{REFERENSI}

Badan Pusat Statistik Kota Cilegon. (2014). Rencana Kerja Tahunan. Cilegon.

Menteri Perhubungan Republik Indonesia. (1995). Keputusan Menteri Perhubungan Nomor 31 Tahun tentang Terminal Transportasi Jalan. Jakarta.

Passini, P. A. (1992).

Wayfinding:People,Signs, and Architecture. Ontario: McGraw - Hill Ryerson Ltd. Reissued as a collector 's edition in 2002 by Focus Strategic Communications, Inc.

Peraturan Daereh Nomor: 02 Tahun 2011 tentang Rencana Tata Ruang Wilayah Provinsi Banten Tahun 2010-2030.

Peraturan Daerah Nomor: 05 Tahun 2012 tentang Rencana Tata Ruang Wilayah Kota Cilegon Tahun 2010-2030.

Technical Memorandum 4. Proposed Regional Wayfinding Signage Program, Wibur Smith Associates, 2005).

http://cilegon.go.id/cilegon -diakses pada tanggal 8 april 2015.

http://hubdat.dephub.go.id/berita/ , diakses pada $10 / 03 / 2015$.

https://www.bps.go.id/linkTableDinamis/view/ id/113, diakses pada 17/12/2015. 



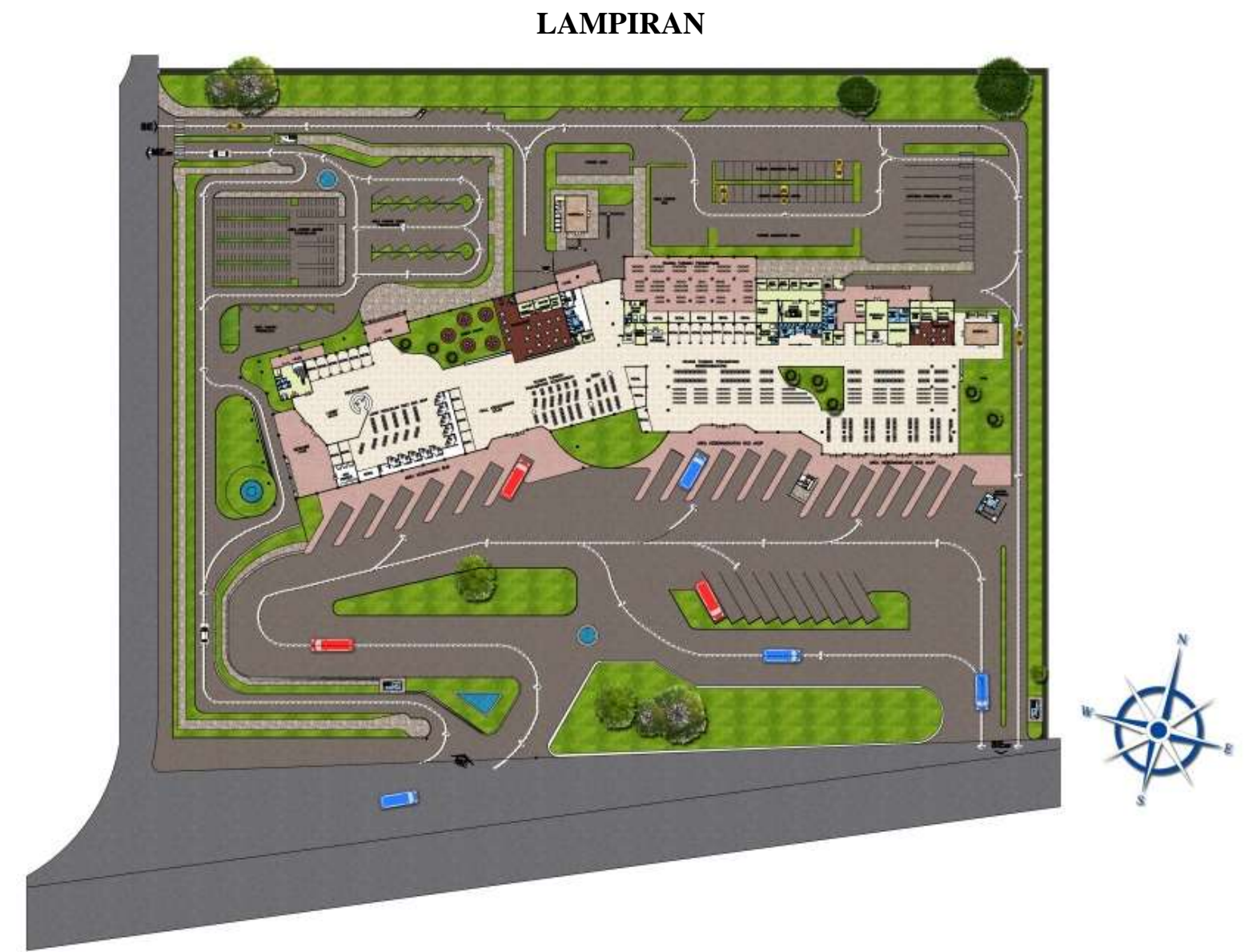

Lampiran 1. Rencana Tapak

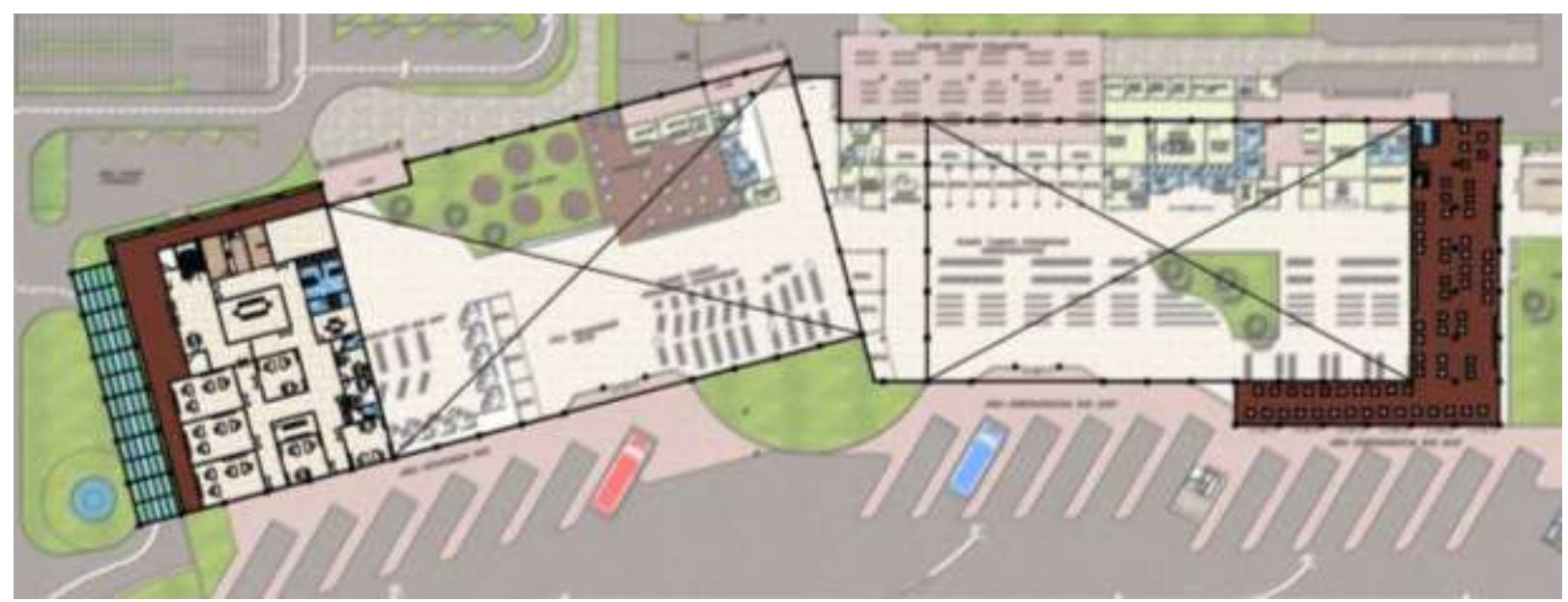

Lampiran 2. Denah Lantai 